\title{
The Alphabet and Orthography of Byelorussian in the 20th Century
}

\author{
BY \\ P. J. MAYO
}

I

At the beginning of the 20th century the Byelorussian language had no officially established alphabetical or orthographical norms. Although many of the characteristic features of Byelorussian pronunciation (e.g. akańnie and jakannie, dziekańnie and ciekannnie, the hardening of $r, \check{z}, \check{c}$ and $\breve{s}$ ) were reflected sporadically in texts as early as the 14 th and 15 th centuries and more frequently - but still with a considerable degree of inconsistency - in the 16th and 17th centuries, ${ }^{1}$ the further development and stabilisation of these features was effectively hindered by subsequent historical circumstances, in particular by the suppression of Byelorussia's national identity, one aspect of which was the treatment of the Byelorussian language until the end of the 19th century as a dialect of Great Russian (malorusskoje narečije).

The writers of works which appeared in the second half of the 19th century and the first few years of the 20th century had no specifically Byelorussian orthographical traditions on which to draw. Accordingly, their works, published in either Latin or Cyrillic script, were characterised by a variety of graphical symbols, largely based on the Polish or Russian alphabets, and by somewhat arbitrary orthographical systems. For example, the sound [w], in addition to being represented by the symbol y as it is in modern Byelorussian, was also written as у (постановіу) or в (правду) and in Latin script as $u$ (zausiody); io occurred not only in Latin script but also in Cyrillic where modern Byelorussian has ё (завоіоваць, вясіола); $i$ was used in Cyrillic texts only in accordance with the pre-1917 Russian convention i.e. before a vowel - elsewhere и was used (дзикіе, на сьвеци, тольки); the softness of c, 3 before another soft consonant was generally reflected in the spelling (часьци, зьвер), but lengthened consonants were not normally spelt double (жыце). Akańnie and jakannie were reflected with varying degrees of consistency, the latter rather more regularly than the former (сиратогі, радасьць, дабром, skańczeńie, hołas cf. одного, перэд, продаваць, czereda, hołas; блда, вясіола, piarwiej, siale cf. перэселяцьца) ${ }^{2}$.

Clearly there was a need for standardisation of both alphabet and orthography, and this need became even more apparent in the first decade of the 20th century when at a time of growing national consciousness Byelorussian publishing houses were established in Minsk, Vilna, Kiev and St. Petersburg. ${ }^{3}$ The first of these, Zahlanie sonca $i \breve{u}$ naša vakonca, began operating in St. Petersburg towards the end of 1906; almost simultaneously the first legal Byelorussian 
=ส̇paper, Naša dola, was published in Vilna. Naša dola was to have i- jrt life: the tsarist authorities confiscated the first five issues and $\therefore$ ihe sixth closed it down. In November it was succeded by Naša t::ב. among the regular contributors to which were the authors I-jała, Kołas, Ciotka, Hartny, Biadula and Bahdanovič. Since there r $:=$ at this period no officially codified norms, these publications $\therefore$ - a significant role to play in the establishment of the alphabetical, :- - Jgraphical and grammatical norms of the Byelorussian literary --juage. Their normative influence was particularly marked where $\because=$ a: phabet was concerned.

Elom the very beginning Naša dola, Naša niva and the publications $\because$ Zahlanie sonca $i \breve{u}$ naša vakonca were printed in both Latin and $\because$-Ilic script. The lacinka was based on the Polish alphabet, with $\because=$ addition of $\breve{u}$ for Byelorussian [w]; the Cyrillic script or hrażdan$c=$ on the Russian alphabet, with the addition of $\breve{y}$ for [w], the $\Sigma$ sititution of e for $\mathrm{b}$, $ш ч$ for $щ$, and the elision of $\mathfrak{b}$ after a hard :osonant in word final position (this last anticipating a change which $\mathbf{z}=$ introduced into the Russian alphabet only after 1917).

I: the tacinka the Czech symbols $\check{c}$ and $\check{s}$ began to appear sporadi$\because-\cdots$ in place of the Polish digraphs $c z$ and $s z$. By 1909 they were to $\approx$ i encountered frequently in Naša niva and from 1910 onwards E: $:=m e$ the standard forms; they were also introduced into the -josations of Zahlanic sonca $i \breve{u}$ naša vakonca. On the other hand - newpaper Biełarus continued to use the traditional Polish łacinka - inout these modifications.

in the hraždanka jotated [o] and [o] after a soft consonant were sally represented, as in modern Byelorussian, by ë (and only $\therefore$ :asionally by $i o$ ), although the earliest publications of Zahlanie :- ca i ŭ naša vakonca have йo; in Ciotka's Pieršaje c̀ytańnie (1906) $\therefore=$ fricative [8] and the plosive [g] were differentiated by the $\because=$ bols $\Gamma$ and $r$. Luater, however, these features were not retained: $\ddot{e}$ zecame the standard form, while $\Gamma$ was used to represent both $\doteqdot$-.ative and plosive. Russian и was replaced by $i$ from 1909 onwards i-j by 1914 the apostrophe had ousted $\mathrm{b}$ in its role of separating $z$ :ated vowel from a preceding hard consonant (е.g. падъехаў z:zame пад'ехаў). The Byelorussian Cyrillic alphabet was thus $\therefore$ an:ished in the form in which, despite a number of proposals for Firm in the $1920 \mathrm{~s}^{4}$ - most notably a desire to create special symbols ¿.:- ine combinations дз and джк - it is still used today.

One problem associated with the alphabet which remained -resolved, however, was the question of whether Byelorussian s.jld continue to use both Latin and Cyrillic script. As was noted ise. the earliest publications of many of the publishing houses set up : : : e beginning of the 20th century and especially Naša niva and its izisciated publications (calendars, various supplements) were proz-zed simultaneously in both. This was inevitably an expensive and =-e-consuming operation, so much so that in its issue no. 50 for 1911 $=-=$ editors of Naša niva posed the question as to which of the two 5:-?ts should be adopted to the exclusion of the other (Jaki šryft :jrac dla biełaruskich drukaŭ?). This was the signal for a lively 
debate: answers flooded in to the editorial board not only from all corners of Byelorussia itself, but also from the Ukraine, Russia and even from distant Siberia where, as Naša niva somewhat coyly expressed it 'there are many of our brothers' ('jość šmat našych brato $\left.\breve{u}^{\prime}\right)$. Some of this correspondence was reproduced in issues $4,5,6$ and 8 for 1912 in a column entitled Conversations with our readers (Hutarky $z$ čytačami).

While a few correspondents favoured the retention of both scripts (one argument advanced in support of this was that the adoption of a single script would drive a wedge into national unity by divorcing Orthodox from Catholic and by creating a cultural division between East and West $\left.{ }^{6}\right)$, the majority agreed with Naša niva - there should be a single Byelorussian alphabet ${ }^{7}$. What remained in dispute was which alphabet should be chosen. Among the arguments put forward in favour of the hraždanka were that it was the alphabet in which the Lithuanian Statute, the first Byelorussian secular book, appeared ${ }^{\mathbb{8}}$; that the majority of Catholics were familiar with it from school, whereas the reverse was not true"; and that the Orthodox population of Byelorussia was three times as large as the Catholic population ${ }^{10}$. The lacinka was preferred by others on the grounds that the Latin alphabet was widespread among 'cultured' nations and was being adopted by many nations which had formerly used their own script; and that in any case it conveyed the characteristics of Byelorussian 'better and more clearly' than Cyrillic ${ }^{11}$. A small minority favoured the creation of an entirely new alphabet which would 'satisfy all the requirements of the Byelorussian language' 12 (though these were not defined).

After the publication of this correspondence there was a threemonth hiatus before Naša niva returned to the subject, once again under the heading Hutarky $z$ čytacami $i^{13}$. Although in the meantime the published correspondence had started a fresh avalanche of letters, none of these were published since they added nothing new to the discussion but simply reiterated previous arguments. It was now time to reach a decision. The creation of an entirely new alphabet was rejected on the grounds that in current circumstances it would be impossible to teach such an alphabet to Byelorussians and that its introduction would retard Byelorussia's renaissance (adradžeńnie) by some decades. The main arguments in favour of the zacinka and hraždanka were summarised and the editors made two further points: far more readers were in favour of the hraždanka than the łacinka, and twice as many copies of Naša niva were sold in Cyrillic script as in Latin.

To Naša niva all the signs pointed in one direction: in future the newspaper should be printed only in Cyrillic or 'Russian letters' as Naša niva termed them. This decision was not, however, implemented immediately. Naša niva continued to appear in both Latin and Cyrillic script until issue no. 42 for 1912 when, in a leading article surveying the six years of the newspaper's existence, the editors announced that henceforth Naša niva would appear only in 'Russian 
-pt'. This was presented as the lesser of two evils - the alternative Tas to cease publication altogether ${ }^{14}$.

iaša niva's choice of the Cyrillic alphabet was eventually mirrored = Bvelorussian as a whole, but not until some time after the 1917 Evolution was it gencrally adopted, at least in Eastern Byelorussia. Significantly, at the 1926 conference on the reform of the alphabet -ad orthography even the most vociferous critics of the existing z źlanka (e.g. Ja. Losik) rejected any suggestion of a return to the icintia. In Western Byelorussia, however, the lacinka continued to se used alongside the hrażdanka right up to the Second World War.

\section{II}

If the standardisation of the Byelorussian alphabet was a relatively इ-ift and painless affair, the same could not be said of the establishzent of the orthographical norms of modern literary Byelorussian. Orthographical rules have been a contentious issue from the publica=on of Taraškievič's Biełaruskaja hramatyka dla skot in 1918, through ie reforms of 1933 and 1957 and, for some at least, remain so to the E-esent day ${ }^{15}$.

The normative influence of Naša niva, which played such an =oortant part in the establishment of the modern Byelorussian zohabet and in the ultimate adoption of the hraždanka in preEerence to the łacinka, was less evident where the orthographical siem was concerned. The lack of an officially codified system of =ims, the fact that it was not yet clear which dialect was to form -e basis of the emergent literary language, the varied linguistic jackground of the contributors - all these factors combined to =eate a situation of some flexibility. Nevertheless it is possible to certain general tendencies at work: the orthography of vowels - as based largely on phonetic principles while that of consonants was sased on morphological (or etymological) principles, as was the soiling of loan-words.

In the vowel system strong non-dissimilative akannie was the norm, zu: there were some restrictions on this, especially in a final open șlable (e.g. маюць права - маюць право, згарэло, ад добраго ๘аго коня), and with rare exception $э$ was preserved in unstressed position (е.g. можэм, морэ, хочэцца). Jakańnie was regularly reflecied $\exists$ the immediate pre-tonic syllable only if the vowel under stress was sot a (e.g. бяз глебы, весялей, вядомы, бярэ, зямлі); if the stressed Fllable contained the vowel a, unstressed e in the pre-tonic syllable zemained (е.g. ваеваць, земля, непраўда), as it did in all other sllables, both pre- and post-tonic (e.g. без народу, вецер, поле, демпнe). Loan-words, proper names and toponyms were usually exempt from these 'norms' (e.g. зоологія, тэлефрон, Достоеўскі, Oraca).

The main characteristics of consonant orthography at this period ग्रе: hard p (е.g. курыць, на рэку); the change of л, в after a vowel - 5 (е.g. воўк, малакроўе, са ўсімі дапаўненнямі) though with some Iuctuation, particularly in foreign names (е.g. Владыслаў - Уладзі- 
мір); the doubling of consonants before [j] (е.g. аткрыцьце, гальлё); a sporadic tendency to replace the original double consonants of loanwords by single consonants (e.g. прэса, тэлеграма but cf. мaсca, прэсса, сумма); dziekańnie and ciekańnie in native words but no softening of д, т in loan-words (е.g. дзержаць, меціць, сf. акадэмія, тэатр); the preservation of the hardness of many other consonants in loanwords (е.g. газэта, сыстэма, мэбля, маніфэст) and of the softness of $\pi$ (е.g. фрілёзаф, парлямэнт). Assimilatory softening was not reflected in the spelling in the early years (1906-7) of Naša niva (e.g. жаданне, жыцщё) but in later issues was indicated by the use of in the Cyrillic and of the acute accent in the Latin script e.g. жыцьцё, letannie); assimilation of voiced and unvoiced consonants was not generally reflected, although there was some inconsistency where prefixes ending in д were concerned (cf. адказ - атказы); the orthographical representation of other consonant assimilation showed no discernible pattern. Thus changes in the groups цств $>$ цтв, шетв $>$ ств, тск $>$ цк and зск $>$ ск were reflected in the spelling (e.g. выдавецтва, таварыство, брацкі, чалавецкі, рубяжэвіцкі, францускі) but those in the groups дзтв $>$ цтв, жкств $>$ ств, дзк $>$ цк were not (е.g. сьледзтва, множства, людзкі).

None of this, however, was systematised and the same word or group of sounds frequently showed inconsistencies of spelling, sometimes in one and the same article (cf. жыта - жыто, ёсьць - ёсць, яго - ешчэ etc.) ${ }^{16}$ For this reason it would be difficult to exaggerate the importance for the development of the modern Byelorussian literary language of the publication in 1918 of Taraškievič's Biełaruskaja hramatyka dla skot. This is equally true of the morphology and of the orthography of Byelorussian, although it is the latter with which we are concerned here.

Biełaruskaja hramatyka dla skot was not the first published attempt at codifying the orthographical norms of Byelorussian; in 1917 the Losik brothers had published, in Latin script, their pamphlet Jak pravilna pisać pa-bietarusku, which they followed in 1918 with Bietaruski pravapis, also in Latin script and clearly based on their previous work. 1918 also saw the publication of two other works which were at least partially concerned with orthographical questions: Prosty sposob stacca $\breve{u}$ karotkim časie hramatnym which strongly, if not always consistently, advocated the phonetic principle of 'write as you speak' ${ }^{17}$, and B. Pačobka's idiosyncratic and unscientific Hramatyka biełaruskaj mowy.

Taraškievič's grammar stands out because when it appeared (also, initially, in Latin script but this was soon followed by a Cyrillic version) and without any official imprimatur, it was widely adopted for use in schools, thereby exerting a strong normative influence. Between 1918 and 1921 it went through four editions ${ }^{18}$. More importantly, at this embryonic stage of the modern Byelorussian literary language Biełaruskaja hramatyka dla skot laid the foundations for its future development, foundations which remain substantially unaltered to the present day. In the words of the authors of Historija 
: ¿icruskaj litaraturnaj movy, II; 'The first school textbook compiled i- ind fifty years ago, even today in many respects represents a $=-$ posis of the normative grammar of the Byelorussian literary ;-_iage'19.

$\therefore$ the introduction to the first edition of his grammar Taraškievič - : gnised the need for a period of flexibility in the form of the -...ten language in order to ensure that the most suitable dialect

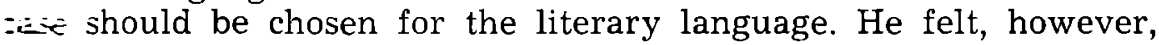
$=:$ : the time had now come to make a choice and Bietaruskaja hra-.: ykia dla skol was therefore based on what he regarded as the most $=$ =-acteristic dialect of Byelorussian, namely that with hard $p$ and :-ong akannie (although he imposed certain restrictions on the latter $\because \because$ ew of the 'long practice of the written language') ${ }^{20}$.

Continuing, but at the same time systematising, an earlier tradition,

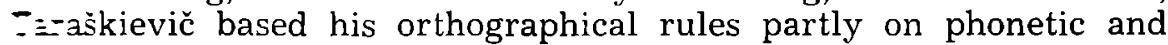
a-rly on morphological principles ${ }^{21}$. Thus pronunciation norms pro-ied the justification for the use of only the non-jotated vowels 之. J. $\mathrm{y}$, э, b after the hard consonants $ж, ч, ш, \mathrm{p}$, for writing double

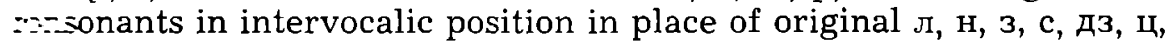
п. $¥$ and $ш$ followed by [j], for the spellings ры, лы, лі in unstressed s:s:-ion where Common Slavonic had had sonant + jer (e.g. дрыв=іь, блыха́, блішча́ць), for prothetic в, г, for the change of в to $\breve{y}$ i-ier a vowel and before a consonant, and for the representation of $=\equiv$ softness of $3, c$, дз, and ц before soft dental and labial consonants ‡. зьняць, сьляза, дзьве, цьвіцець).

With unstressed vowels the picture was somewhat more compli$\because:$ ed. It is in this area more than any other that Byelorussian dialects - jw a wide variety of pronunciation; any practical system of orthoइ-aphy could not hope to reflect all the changes, of both quality and - -antity, which take place at various degrees of removal from the :-:-essed syllable even within a single dialect. Taraškievič therefore smpromised between his two basic principles: unstressed 0 , э were $\because$ be written everywhere as a except in certain loan-words (see छe:ow) and a number of numeral-words (e.g. восемна́ццаць, щэсць(r) : unstressed e was to be written as $\mathrm{g}$ in the immediate pre-tonic Fiable regardless of the vowel under stress, (also with exceptions $\therefore$ - loan-words and certain numerals e.g. семна́ццаць, дзевя́ты), - ile in the second pre-tonic syllable jakannie was to be dissimi三:: үe (е.g. лясуна́, бядуна́, ня была́, бяз дзіця́ці but цецяру́к, не

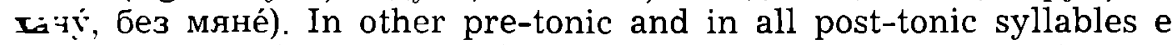
๙as to remain (e.g. верацяно́, вóсень, по́ле, ду́маем); exceptions to $\because$ s rule were made for certain grammaticised endings. ${ }^{22}$

By contrast with vowels the orthography of the consonant system - as based almost entirely on morphological principles. With very few ixceptions consonant assimilation - voicing and devoicing, the ¿sappearance of consonants in certain consonant groups - was not $=$ =flected in the spelling; the devoicing of consonants was reflected :-ly in the case of prefixes ending in 3 (e.g. згінуць, разбіць but хадзіць, рассыпаць), while the disappearance of consonants in 
pronunciation was reflected only in the groups жс, зс, стн and здн (е.g. боскі, францускі, пачэсны, позны).

Taraškievič separated loan-words into two groups: those which had long since been assimilated into Byelorussian, and those which were current in the literary language but had not yet penetrated the vernacular or had only recently done so $^{23}$. The former were to be written according to the normal orthographical rules of Byelorussian (е.g. літара, аканом, калідор, леварвер); the latter according to their spelling in the language from which they were taken (е.g. тэлеграф, географія, універсытэт, элемэнт). This was, of course, a subjective division and not surprisingly became one of the focal points of dissatisfaction with Taraškievič's orthography in the 1920s.

Two general rules which Taraškievič applied to loan-words of both types were that double consonants in the original language should be replaced by single consonants in Byelorussian (е.g. тэлеграма, каса, маса) and that foreign $l$ was to be represented in Byelorussian by soft л (e.g. лямпа, Лёндон, монолёг). Both these features were characteristic of Byelorussian pronunciation.

If we compare Taraškievič's orthography with that which had gone before, especially in the Naša niva period, we can see that in addition to regularising certain tendencies already strongly in evidence at that time (the change of $\pi, \mathrm{B}$ after a vowel to $\mathrm{y}$, the assimilatory sofiening of consonants, the preservation of soft $\pi$ in loan-words etc.) Taraškievič introduced rules which extended or in some instances ran counter to current practice. Akannie was no longer restricted in a final open syllable and also became the norm for unstressed 9 , where previously this had been exceptional; dissimilatory jakannie became a feature of the second rather than the immediate pre-tonic syllable; the previously sporadic replacement of double consonants in loan-words by single ones was given the status of a norm.

Notwithstanding the general excellence of Taraškievič's work and its widespread adontion it was perhaps inevitable that some problems should have been resolved less than satisfactorily. Taraškievič himself acknowledged as much in the introduction to the first edition of Bietaruskaja hramatyka dla skot, but added that he hoped that any changes which were felt to be necessary would not be too great and that 'all the most important things had been done well'24. While the subsequent development of the Byelorussian literary language has shown that all the most important things had indeed been done well, Taraškievič's orthography had two main defects: in the treatment of unstressed e, and in the artificial separation of loan-words into those which had penetrated the vernacular and those which were confined to scientific and literary usage, with a consequent difference in the application to those two groups of the rules governing akaninie (and jakannie). It was these two areas which were to attract most of the attention of those who were seeking to reform the orthography of Byelorussian in the 1920s.

The first overt sign of dissatisfaction with Taraškievič's orthography was the extension of akannie to many loan-words which, in Taraškievič's words, 'had not yet reachcd the people'25, from 1922 
זrards in the newspaper Savietskaja Bietaruś, although only in the च of unstressed o e.g. кангрэс, шавінізм but рэкашэтам, тэрмінаIf-A). This was also illustrated in the dictionaries compiled by TËraševič, Bajkoŭ and Harecki². From 1924 a number of articles J:ed to this and other orthographical problems began to appear If: continued to do so throughout the $1920 \mathrm{~s}^{27}$.

Fe most far-reaching and in many ways the most controversial of ZE was the Losik brothers' $D a$ reformy bielaruskaha pravapisu. $Z$ Ey proposed the following major reforms: the simplification of the - es governing jakańnie by writing я for unstressed e in all syllables; ie extension of akannie (in the case of unstressed o) and jakańnie i: aan-words, with exceptions only for some compound words; the wizion of the soft sign after the consonants 3, с, дз, ц before other $\mathbf{x} \div$ - consonants and also between so-called 'double' consonants; the Exition of $y, i$ after a vowel in word initial position or when =ding as separate words.

Iazep Losik, in particular, campaigned so effectively for consideraze of these reforms that the Scientific Council of the Institute of E-:orussian Culture created a special Orthographical Commission Ėr the chairmanship of A. Cvikievič to examine the Losik I-:iers' project. The Commission, however, was unable to reach E- Emen $\hat{\imath}$; the Scientific Council therefore decided to call an $\underline{\Sigma}=$ jemic Conference on the reform of the Byelorussian orthography zㅜ ziphabet. This conference, which was attended by leading scholars :-: only from Byelorussia itself, Russia and the Ukraine, but also -EFoland (Golombek), Germany (Vasmer) and some other European =-ciries, was held from 14-21 November 1926 and the speeches and zarts of the various commissions were published in $1927^{28}$. Sadly - $-\overline{-}$ ikievič, together with other Western Byelorussian scholars, was Is:-:ented from attending because the Polish government would not sie them with passports.

$\therefore$ inough the conference was concerned with the Byelorussian --abet and the language of Byelorussian literature as well as orthoDinical problems, it was the last of these to which it devoted the E:est attention and which generated the most intense discussion. -E main speeches on this subject were given by Jazep Losik and 三 Niekraševič, with shorter contributions by, among others, Anton - . V. Voŭk-Levanovič, P. Rastorgujev and the Ukrainian P. A. Đik. Some speakers argued for fundamental reforms in Taraškie$-\vdots \Sigma$ orthography and favoured considerable extension of the phonetic Irapie, on the Serbian model; others proposed less drastic تriasures, consisting in the main of a tying up of the loose ends left $\because$ Taraškievič. The only point of general agreement was the extens:- ai alianie (in the case of o only) to loan-words.

Ize main proponent of substantial reform was Jazep Losik. This F n 5 t surprising in view of the fact that it was largely as a result :- : :s campaigning that the conference had been called. In his speech - Eepeated the proposals outlined by himself and his brother Anton $=-\because e: r$ pamphlet Da reformy bietaruskaha pravapisu (see above). was disturbed by what he felt to be a fear of change and the 
uncritical acceptance of Taraškievič's orthography, which was rapidly becoming a sacred cow. He was critical of the etymological principle in orthography on the grounds that it was incomprehensible to the masses and he cited English and French as particularly bad examples. Only the phonetic principle could satisfactorily answer the need for a readily accessible orthography; it should therefore be extended not only to the spelling of unstressed vowels in loan-words, but also to the consonant system of Byelorussian in general. Some degree of phonetic spelling of consonants was already in operation (e.g. бpaцкi, францускі, пачэсны). Why should not such forms as мёт, хлеп, ношка, калотка (for мёд, хлеб, ножка, калодка) be equally acceptable? Paradoxically, Losik criticised Taraškievič's rules for jakańnie precisely on the grounds that vowel changes in unstressed syllables were a matter for phonetic transcription and not for the orthography!29

With the exception of the extension of akannie to loan-words Losik's proposals received little support from the other contributors. Rastorgujev gave his qualified approval to the extension of jakannie, but warned against going too far - nowhere in Byelorussia did one hear, for instance, пяравярнуць ${ }^{30}$; Buzuk was in favour of the phonetic representation of consonants - the Serbs had shown that there was nothing to fear in this ${ }^{31}$; but the retention of $i, y$ after vowels and the abolition of $\mathrm{b}$ after $3, \mathrm{c}$, дз, ц before other soft consonants and between double consonants found almost no support.

Where Losik talked of an 'orthographical crisis's2, the other main speaker at the conference, Niekraševič, counselled caution: there was no crisis, Taraškievič's orthography generally held good, certainly nothing better had as yet emerged. He claimed the support of the absent Western Byelorussian linguists in this and accused the Losik brothers of putting orthographical principles before pronunciation and of adopting an unscientific approach in their pamphlet ('uvieś pravapis, možna skazać, budujecca $z$ hałavy') ${ }^{33}$ which hardly merited the calling of a special conference. Niekraševič was not convinced of the need for reform, except with regard to the extension of akannie to loan-words. Apart from this he suggested only a couple of minor amendments to Taraškievič's orthography: the elimination of jakañnie from the second pre-tonic syllable and from не and 6 es when written as separate words.

After the speeches and discussions the various proposals were passed to an orthographical commission for further consideration. The commission rejected almost without exception those put forward by Jazep Losik (the extension of the phonetic principle to the spelling of consonants, jakannie in all unstressed syllables etc.) but recommended the adoption of Niekraševič's suggestion concerning the elimination of jakańnie in the second pre-tonic syllable and from не and без when written separately; it also approved the extension of akańnie to loan-words as outlined by Niekraševič, i.e. in the case of o only (cf. камісія, but дэлегат). The commission's other recommendations were: that i should not be replaced by $\breve{И}$ when it occurred after a vowel as a separate word or in word initial position, but that $y$ 
sid continue to be replaced by $\mathrm{y}$ in such positions; that the remain$=$ points of reform which had been raised at the conference (e.g. abolition of $\mathrm{b}$ after $\mathrm{c}$, дз, ц and between double consonants) should $z=$ referred to the Orthographical Commission of the Institute of E.:-irussian Culture.

-araškievič's orthography thus emerged from the conference Eively unscathed. The elimination of jakannie from the second :-E-onic syllable regardless of the vowel in the immediate pre-tonic - -ajle represented a welcome simplification of Taraškievič's rules $\therefore$ id the standardisation of the spellings не and без when these $\dot{-1}=-$ : were written separately. The extension of akannie (for unscessed o) to all loan-words was also welcome since it eradicated the io io apply subjective criteria in determining the spelling of such -: ds - perhaps the weakest point in Taraškievič's orthography. =- limitation of this change to unstressed o, however, was unfor- -ate, since it meant that the treatment of unstressed 9 in loan-:-ds remained subject to these same subjective criteria and created istinction between, on the one hand, the treatment of unstressed

$\therefore 3$ in native words and loan-words assimilated into Byelorussian - -. золата, вада, рака, чарапы, камісія, аграном, адукацыя, акаझ:s) and, on the other, their treatment in more recent loan-words -:ch were regarded as not having penetrated to the vernacular e.g. з-рафія, батаніка but літэратура, рэдакцыя) - a distinction which - $=$ - argely persisted to the present day.$^{35}$

Une change in Taraškievič's orthography which ran counter to the $\sim>$ i of simplification and consistency was the proposal to retain i in as-syllabic position where it occurred as a conjunction or in word -::al position (e.g. баба і дзед, баба ідзе) - a change which was the =o:e surprising in view of the opposition which had been expressed $\because \because$ : he majority of contributors to the conference when Jazep Losik

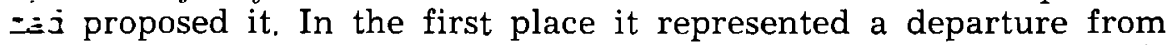
= general phonetic principle underlying the orthography of vowels = Bvelorussian; secondly, it introduced an unnecessary complication $=: 2$ the rule governing the treatment of this vowel, since it was to $\because-:-$ nue to become $\breve{~}$ internally in a word or in word final position z. свойскі, бадай, людзей); and thirdly, it was inconsistent with $=$ treatment of the vowel $y$ in similar circumstances, since the z: ference rejected a parallel proposal to abolish the change of y to $\therefore$ Nevertheless this inconsistency is still in evidence in the orthoz-aphy of Byelorussian today.

\section{III}

The conference over, work on the orthography (and, to a lesser Ex:ent, the alphabet) continued in the Institute of Byelorussian - - ture. On the 1 October 1927 a Commission on the Literary Lan=-age was created and was charged with the task of examining all $\because=$ material from the 1926 conference with a view to producing a $\vdots=$ :nitive orthography. This commission in turn appointed a special $0-$-nographical Commission whose members were: S. Niekraševič 
(chairman), A. Bahdanovič (secretary), Jazep Losik, V. Eastoŭski, P. Buzuk, Ja. Bialkievič, Ja. Łucevič (Kupała) and U. Caržynski. Between 7 December 1927 and 17 April 1929 it held 33 sessions. Working on the principles that 1) orthographical reform should be separated from the reiorm of the alphabet and that the orthography should be reformed first on the basis of the existing alphabet; 2) the findings of the 1926 conference were to be regarded as authoritative, but not binding; and 3) taking into account the value of Taraškievič's orthography, only those changes and additions which would simplify and improve it should be made, the Orthographical Commission produced a plan for the orthography of Byelorussian which was published by the Academy of Sciences in $1930^{36}$.

Meanwhile a fifth, revised, edition of Taraškievič's Biełaruskaja hramatyka dla skot was published in Vilna in 1929. In his introduction to this edition Taraškievič explained that, while he recognised the need for some reform, he had not introduced any of those changes which had been approved by the 1926 conference because he felt that any reform of the orthography should be carried out as a whole and in conjunction with a reappraisal of the grammar. Piecemeal changes could only lead to 'harmful chaos' ('škodny chaos'). This view was echoed by $R$. Astrousski in the introduction to the second edition of his Biełaruski pravapis ${ }^{37}$, which was based on Taraškievič's orthography, but in a considerably expanded form.

The 1930 prajekt went a long way towards answering Taraškievič's criticisms. Its proposals for orthographical reform were made in the context of the orthography as a whole (in many respects it endorsed Taraškievič's orthography) and 13 of the 62 recommendations were concerned as much with grammar as with orthography e.g. there were recommendations on the use of the endings $-a$ and $-y$ in the genitive singular of masculine nouns of the second declension and on the endings to be used in the second person plural of the present/ future tense and imperative mood of verbs ${ }^{38}$. As for the orthography itself the prajekt covered all the controversial issues of the 1920s. It considered the spelling, of loan-words in much greater detail than had Taraškievič, devcting approximately one third of its recommendations to this subject ${ }^{39}$, and also had a special section on the orthography of proper nouns and toponyms, something which Taraškievič had not dealt with at all'0. An appendix to the consensus recommendations contained the comments of various members of the Orthographical Commission on individual points in the prajekt ${ }^{41}$.

In the main the prajelct incorporated the recommendations of the 1926 conference. It did not, however, accept the standardisation of the spelling of He and $6 \mathrm{e}_{3}$ when written separately, and it advocated the retention of syllabic y (as vell as i) when it occurred after a vowel as a separate word or in word initial position ${ }^{42}$. Otherwise its only major departures from Taraškievič's orthography were in recommending the abolition of 5 after 3, , дз, In before another soft consonant and in double consonants, and of the use of the apostrophe (instead of b) after soft consonants as well as hard before jotated vowe]. ${ }^{43}$. 
One may question the need for some of these changes and how i- they accorded with the Orthographical Commission's brief to Eże only those changes which would 'simplify and improve' the sting orthography - particularly the retention of syllabic $y$ and $i$ $E d$ the abolition of $b$ in the circumstances referred to above; what $=-n 0^{2}$ be doubied is that the prajekt was the fruit of much thought- . scholarly consideration of the issues involved. Sadly it was -ined to remain merely a prajekt; when an official decree detailing =csiderations had superseded linguistic and practical ones.

$3 y$ this time many members of the Orthographical Commission - ch had produced the 1930 prajekt were in prison (e.g. Buzuk) or II ex:le (e.g. Niekraševič), accused of 'bourgeois nationalism'. The Izoduction to the 1933 decree lcaves us in no doubt as to their $=e^{\prime}$ :

- Byelorussian national democracy, proceeding from its bourgeois, counter-revolutionary aims, has carried out its subversive saboseurs' work on both the economic and the cultural front, including the sphere of language, terminology and orthography. Tational democracy has striven by all means possible to divorce :he Byelorussian literary language from the language of the broad working masses, erected an artificial barrier between the Bielorussian and Russian languages and contaminated the Bielorussian language with various medieval archaisms and jourgeois vulgarisms.

The existing Byelorussian orthography has been considerably contarininated by these stated tendencies and is therefore in need of reforms's.

Z: $:$ indictment of the work carried out at the Institute of Byelo- Issan Culture during the 1920s was expressed in even more prop-distic and vitriolic terms at a general assembly of the writers If insk called by the Institute of Linguistics of the Byelorussian $-2=$ jemy of Sciences and the Organisational Committee of the Union ir Sriet Writers of the BSSR in December 1933. After a lengthy joress by $A$. Aleksandrovic entitled 'The class struggle on the - : s:ic front and the reform of the orthography of the Byelorussian II. Jage' there followed a number of shorter contributions, by, among :-ers. Kołas, Biadula, Krapiva, Łyńkoŭ and Broŭka. These were $\because=$ sned in 1934 , together with a written submission from Kupała, Z: ras convalescing in Kislovodsk, in a volume entitled 'The Writers $\vdots=$ BSSR about the Reform of the Orthography of the White₹-i=n Language'46 — although a less misleading title might have $x \div=$ - The Writers of the BSSR about National Democracy', since the out:ons had rather more to say on that subject than about the itself.

I-e s:yle of the contributions varies little: the 'national democrats' $=$-ariously aligned with interventionists, the White Guard, Polish ins_s.s. Hitler and German fascists; Niekraševič Jazep Losik, Jizoūka and others associated with Polymia and Uzvyšša are singled 
out for particular venom. The supremacy of the political aspects of the reforms is perhaps best illustrated by Jakub Kołas, who sees three principles at work: the political, the scientific and the practical in that order ${ }^{47}$.

Predictably, the 1933 decree evoked a hostile response from linguists in non-Soviet Byelorussia and this was exemplified in the publication of a protest against the reform of the orthography by the Byelorussian Scientific Society in Vilna ${ }^{18}$. This document was the outcome of an extraordinary general meeting of the society held on the 31 October 1933 at which a resolution was passed condemning the decree as 'a political act which, trampling on the demands of science, outraging Byelorussian grammar and violating the living Byelorussian language, has as its aim the fusion of the Byelorussian literary language with Russian and the gradual, systematic Muscovisation of the Byelorussian people'+9, and calling on all participants in the 1926 conference to add their voice to the protest. Although it was also not without political overtones, the protest of the Byelorussian Scientific Society did at least attempt a linguistic analysis of the changes in the orthography brought about by the 1933 decree. In doing so it found that in approximately half the changes there was an element of Russification.

One of the most vociferous opponents of the 1933 decree in Western Byelorussia was Janka Stankievič who in 1936 published, at his own expense, a pamphlet denouncing the reforms and the motives behind them ${ }^{50}$. He was to remain a critic, both theoretical and practical, over the next quarter of a century. In 1947 he published a grammar of Byelorussian ${ }^{51}$ which completely ignored the orthographical reforms of 1933 (although it must be said that his own conception of the Byelorussian language was in many respects idiosyncratic), and in 1955 he returned to the subject of his 1935 pamphlet in rather more detail in an article in the émigré publication Biełaruski zbornik ${ }^{\mathbf{5 2}}$.

In the face of all this it is easy to overlook the fact that in a number of its 23 paragraphs the 1933 decree implemented reforms which had been suggested by the 1926 conference and/or the 1930 prajekt. While there can be no question that the decree was largely politically motivated (why else should a special category of 'international revolutionary words' be created which were specifically exempted from the rules of akannie?), a critical evaluation of the individual points of reform suggests that it was not as completely against the spirit of the Byelorussian language as has been claimed by some of its opponents.

\section{IV}

The 1933 decree proposed three changes in the orthography of the Byelorussian vowel system: the limitation of jakannie to the immediate pretonic syllable, the standardisation of the spellings не and 6eз when these were written as separate words, and the use of prothetic $\mathbf{B}$ before initial stressed $\mathrm{o}, \mathrm{y}$ and also before initial unstressed y where this latter was not a prefix or derived from B. Leaving aside for the moment the last of these changes (which might in 
$\Sigma \because$ case have been more appropriately included under the section :c the orthography of consonants), we find that the other two zrovosals coincide entirely with those put forward by Niekraševič at $=1926$ conference and recommended for adoption by the OrthoExnical Commission of that conference. (Subsequently in the 1930 - elit the proposal to standardise the spelling of не and без was inded; не and без were to be regarded as a syllable of the follow=- word and be spelt accordingly (i.e. не крычь́, без людзе́й but ня 泣: бяз нác). Both these changes represented a departure from - E-askievic's orthography. How far were they justified?

$3 y$ contrast with unstressed o there is a much greater variety in the -siment of unstressed e in Byelorussian. Not only are there conĖzable differences from dialect to dialect, between dissimilative Z-: non-dissimilative jakańnie, jakańnie and ikańnie, but also in = $=\mathrm{r}$ cases from syllable to syllable. Clearly it was impossible to ic - ise an orthographical rule to take account of all these variations. Y: would it have been appropriate: such a task falls more properly - : in the domain of phonetic transcription. Any orthographical rule W: iherefore bound to involve some simplification of the pronuncia$=\therefore$ norms. With Taraškievič this had taken the form of nonEs:milative jakańnie in the immediate pre-tonic syllable and -similative jakannie in the second ${ }^{53}$; the 1933 reform simply went i s:age further by abolishing jakannie altogether in the second pre$\because:-:$ c syllable. To argue, as Stankievič does ${ }^{54}$, that this goes against $\therefore \geq$ nature of the Byeloruss an vowel system is to misunderstand the -ie of the orthography.

Less satisfactory was the standardisation of the spelling of не and Ez when written as separate words. While from a pedagogical point : : iew there was a clear advantage in this change, it ignored the E:: that even when they are written separately the particle He and :- preposition без are purely syntactic words which in pronunciation Ee no more independent of the words they qualify than are the z-e ixes не- and без-, which were to continue to alternate with няI-d о̆.з- (subject to the new rule of jakañnie).

The other rule which the 1933 decree included under the heading $: \because$ : he orthography of vowels (the use of prothetic $\mathrm{B}$ ) was an accurate, $\because$ incomplete, reflection of Byelorussian usage (it did not deal with -e occurrence of prothetic в before unstressed a, e.g. у вагнí) and was I :ather more precise formulation than Taraškievič's vaguely worded s:-iement that if a word begins with the vowels a, o, y or 9 then it $= \pm r$ be preceded by the aspiration в or $r^{55}$. It also marked a contrast an Russian, which has no prothetic consonants. Stankievič never$\therefore$ :less managed to see an element of Russification in the fact that $\therefore$ rule had been included among those on vowels rather than $\because:$ sonants ${ }^{56}$.

With one exception the five points in the 1933 decree concerned $\pi-:$ in the orthography of consonants implemented reforms proposed in $\therefore$ :e 1930 prajekt. The exception was the retention of a final stem $\because:$ sonant д before the c of a following suffix (e.g. гарадскі, градскі); 
here the 1930 prajekt had suggested the spelling дз (гарадзкі, грамадзкі).

The two most controversial reforms, however, involved the deletion of $\mathrm{b}$ after $3, \mathrm{c}$, дз, ц before another soft consonant and in double consonants. Opponents of the 1933 decree saw them as prime examples of the Russification of Byelorussian. But how far does this charge stand up in the face of the evidence? There is no doubt that with the deletion of $\mathrm{b}$ after the consonants $3, \mathrm{c}$ and, to a lesser extent, $ц$ many words acquired an appearance identical with that of the corresponding Russian word (е.g. свет, след, снег, разведка, цвег), but in the case of дз and double consonants this could not happen because neither the former nor the latter are characteristic of Russian (cf. Byelorussian дзве, заданне, соллю and Russian две, задание, солью). Moreover, these changes had been proposed long before political considerations had begun to impinge on orthographical matters: Jazep Losilk had spoken in favour of them at the 1926 conference $^{57}$ and, although some speakers had feared that they would lead to incorrect pronunciation ${ }^{58}$ and the decision as to their implementation had been left to the Orthographical Commission set up after the conference, the 1930 projekt, (which was the result of that commission's work) had recommended their adoption (with Niekraševič and Kupala dissenting ${ }^{59}$. They were therefore associated as much with the 'nacdemy' as vith the Communists.

Surprisingly, at no stage was it proposed to delete $\mathrm{I}$ in double consonants while preserving it after 3, с, дз, ц. There would have been a csrtain logic in such a proposal, since the so-called double consonants are merely an orthographical device to represent lengthened consonants - the deletion of $\mathrm{b}$ should therefore in no way affect their pronunciation.

The third section of the 1933 decree dealt with the orthography of loan-words. This was an area of the orthography which had received insufficient treatment in Taraškievič's grammar and had been the source of much of the discatisfaction expressed in the 1920s (see above). The 1930 prajelt thed gone some way towards rectifying the situation, devoting approximately a third of its recommendations to this subject, and a number of these were incorporated in the 1933 decree: the extension of alvarnie to loan-words in the case of unstressed o but not э, е (е.g. маналог, прафесар but тэлефон), the use of $\phi$ for foreign $f$ (e.g. форма) and th (e.g. apparpadis), the latter with some exceptions which had become established by tradition with т (е.g. тэатр, метад, тэзіс). In other reseets, however, the 1933 reforms not only went against the characteristics of Byelorussian but were clearly politically motivated and aimed at harmonising the form of much Byelorussian 'international' lexis with that of Russian.

The most blatant example of this was the creation of a special category of 'international revolutionary words' which were exempt from the normal rules of akańnie (рэволюцыя, совет, большэвік, комуна, соцыялізм, комунізм, Комінтэрн, пролттарый). Alongside spellings such as маналог, геаграфiя, камітэт there could be no linguistic justification for these forms. 
Russification was also evident in the treatment of foreign $l$. \pm :hough the 1933 decree recommended the continuation of the Byelo-isian practice of representing European 'middle $l$ ' sometimes by i iard л (е.g. метал, пратакол, формула) and sometimes by a soft л -.g. пляж, лямпа, пляц), it claimed, totally falsely, that the tradi=anally widespread pronunciation in Byelorussia was predominantly - : in a hard $\mathrm{J}^{60}$, and included among its examples of this a number of :ms which had previously been pronounced (and written) with a soft л (е.g. клас, маналог, калонія). It is no coincidence that the Essian equivalents of all the examples quoted in this section of the Ecree have a hard $\pi$.

Other rules which represented a departure from Byelorussian usage weze those concerning the treatment of foreign $s, z$ as predominantly soit when adapting loan-words into Byelorussian (e.g. сістэма, фiзiхз. the rejection of forms such as пролетар, пролетары in favour of $=\infty$ тетарый (to be declined like май) and of the adjectival declension if nouns in -істы (е.g. комуністы) in favour of nouns in -icт (to be secilined like брат), all of which represent subordination of Byelo-issian linguistic norms to those of Russian.

The one section of the 1933 decree which entirely accorded with -E 1930 prajekt and evoked virtually no opposition from those Byelozissians living outside Soviet Byelorussia was that which was consenned with the orthography of Christian names, surnames and oponyms. Like the 1930 praje!ct the 1933 decree stated that these Eould retain the characteristics of the language from which they Tere taken insofar as these did not conflict with such characteristic 3yelorussian features as alcańnie, dziekannie, ciekannie, the spelling $\therefore$ vowels after chuintantes and the change of $B$ to $\breve{y}$ in syllable final zosition ${ }^{61}$.

In complete contrast the final section of the 1933 decree, which jealt with certain points of morphology, almost entirely contradicted $\therefore$ e recommendations of the 1930 prajekt. Furthermore, with one Exception ${ }^{62}$ the rules given all had the effect of making Byelorussian zammatical forms less distinguishable from the corresponding Russian znes. Nowhere is this more evident than in the statement that masculine nouns in the genitive singular should be written mainly with the endings -a, -я: завода, цэха, трактара, інстытута, соцыялізма. універсітэта, правапіса but жалю, болю, гаю, лесу, краю, э.менту'63. In accordance with Taraškievič's grammar the ending $-a(-я)$ was to be used in Byelorussian only for 1) animate nouns; $\geqslant$ I nouns which can be seen or counted (i.e. concrete objects); 3 ) the zames of months. All other nouns (the majority) normally took the ending $-y(-\circ)^{64}$. On that basis only one of the nouns listed in the 1933 jecree with the ending -a (трактара) conformed to the Byelorussian =orm. In Russian, on the other hand, the ending -y (-ю) is extremely - siricted in its usage: apart from a number of set expressions in ar: $\mathrm{ch}$ it has become fossilised, it is confined to a very small number $\because$ rouns denoting substances and even then is used only when those zouns occur in a quantitative construction.

The other morphological changes contained in the 1933 decree 
which violated the norms of Byelorussian were: the abolition of the stressed endings -óm, -ix in the dative and locative plural of masculine and neuter nouns and their replacement by the endings -ám, áx (e.g. братам, братах); the unification of the oblique cases of the numerals два and дзве (абодва and абедзве) by the abolition of the formerly distinct feminine forms (дзьвёх оr дзьвюх, дзьвём оr дзьвюм, дзьвяма оr дзьвюма), and of the alternative masculine and neuter forms with the stem vowel о (двох, двом, двама), leaving only those forms which coincided with the Russian forms (двух, двум, двума); the standardisation of the ending of the 2 nd person plural of the present tense of first conjugation verbs, regardless of whether they were stressed on the stem or the ending, i.e. not only працу́еце, чыта́еце but also вядзе́це, нясе́це (in place of ведзяцё, несяцё); the replacement of the stressed ending of the 2nd person plural of the imperative mood -е́це (-э́це) by the ending -і́це (-ь́це) е.g. нясіце, бярьiце and, finally, the exhortation 'to introduce into the orthography (sic) of Byelorussian active participles, especially when they have a social meaning' ${ }^{\prime}$. The key word here is 'introduce' - present active participles at least were only rarely used in Byelorussian at this period, a relative clause construction being preferred ${ }^{66}$. The political motives of the 1933 clecree were thus at their most naked in the changes introduced into the morphology of Byelorussian.

\section{$\mathrm{V}$}

The decree came into effect on 16 September 1933; from that date all schools and publishing houses were to go over to the new orthography. Reading between the lines of an article in the issue of Zviazda for that day, we get a clear indication that the new orthography was as unpopular with many people within Soviet Byelorussia as it was in Western Byclorussia. The article refers to the 'as yet not unmasked residue of the 'nacdemy' ' and regrets is that 'some comrades do not understand' that 'the new orthography is one of the concrete manifestations of the struggle the party is waging for the construction of a culture which is national in form and socialist in content'. The Institute of Linguistics of the Byelorussian Academy of Sciences is singled out for particular criticism in this respect. Three years previously the party had rid the Academy of Sciences of its Losiks, Łastoǔskis, Niekraševičes and Ćvikievičes. 'Who gave those people sitting in the Institute of Linguisties the right to guard their legacy so tenaciously? How could it happen that neither the praesidium of the Academy of Sciences nor the party cell noticed this and took steps to cleanse the Institute of Linguistics of these class enemies and their inheritance?' Even Communist writers are indicted for being insufficiently vigilant in 'the struggle with the continuation of the national democratic tendency in linguistics' ${ }^{\prime 67}$.

It was against this background that the decree was enforced. Between 1933 and the beginning of the Second World War a number of grammars and school textbooks incorporating the principles of the new orthography were published ${ }^{6 \theta}$. Dissatisfaction with some aspects 
$\because:$ the decree surfaced publicly in a number of articles in newspapers $\equiv$. d magazines in the late $1930 \mathrm{~s}^{69}$, and again after the war ${ }^{70}$. In 1951 三Prajekt źmien i udak?adnieńniaŭ biełaruskaha pravapisu was drawn $\because$ by the Orthographical Commission of the Institute of Language, - ierature and Art of the Byelorussian Academy of Sciences and its sntents discussed at a conference held in the Institute on 25-26 inuary $1952^{71}$.

Not until 1957, however, did the Soviet of Ministers of the BSSR ssue a new decree ${ }^{\tau 2}$. This decree restored some characteristic features $\therefore$ : Byelorussian morphology which had been abolished in 1933: the s.ressed ending of the 2nd person plural of first conjugation verbs e.g. бераце́, несяцé) and the distinctive oblique case forms for the Eminine gender of the numeral дзве (дзвюх, дзвюм, дзвюма). As ¿ar as the orthography was concerned, however, apart from a Elarification of the rules governing the use of the apostrophe and $b$, and the formulation of rules concerning akannie and jakannie in sompound words, the 1957 decree contained only minor amendments :o its 1933 predecessor - notably the inclusion under the normal rules of akaninie of the 'international revolutionary words' formerly exempted, and the extension of akannie (in the case of unstressed 9 ) and jakannie (in the immediate pre-tonic syllable) to proper names and toponyms of Slavonic origin or which had long since been assimilated into Byelorussian (e.g. Чарнышэўскі, Чарапавец, Нява, Сяргей).

These amendments were incorporated in the first officially codified sandbook of modern Byelorussian orthography - Praviły biełaruskaj arfahrafii $i$ punktuacyi, published by the Byelorussian Academy of Sciences in 1959 - which remains the most recent official statement of the orthographical and punctuation norms of Byelorussian. The shanges introduced by the 1933 decree thus remain substantially in srce to the present day.

\section{Notes}

1. M. R. Sudnik, 'Da pytańnia ab historyi farmiravańnia biełaruskaj arfahrafičnaj sistemy', Vieści AN BSSR, 3, 1950, pp. 48-50.

2. The examples quoted in this paragraph are taken from the following works: W. Dunin-Marcinkiewicz, Sielanka, 1846; A. Rypiński, Niaczysćik. Ballada Białoruska, Tottenham, 1853; Rasskazy na belorusskom narečii, Vilna, 1863; Szymon Reŭka, Smyk bialoruski, Poznań, 1894; A. I., Synok, St Petersburg, 1895; A. I., Skarej u Tomsk, Minsk, 1896; Chto praŭdzivy pryjaciel biednoho narodu?, London, 1903.

3. In 1846 an attempt by the ethnographer Špileŭski to produce the first grammar and codified orthography of Byelorussian had come to nothing. The Academy of Sciences refused to publish his work on the grounds that it was not scientifically based.

4. See especially the contributions by Ja. Losik, P. A. Rastorgujev, S. M. Niekraševič and V. Eastoŭski in Pracy Akademičnaje konferencyi pa reformie pravapisu i azbuki (14-21 listapada 1926 h.), Inbiełkult, Minsk, 1927, pp. 11565; also U. Duboŭka, 'Projekt litar dla zhukaŭ "dz" i "dž"', Uzvyšša, 1928, No. 4., pp. 161-77; 'Biełaruski zhuk "dz" i litera "dzelo"', ibid., No. 5., pp. 183-91.

5. Naša niva, 1912, No. 4.

6. ibid., No. 8. 
7. One correspondent pointed out that in 1908 only 28 issues of Nasa niva had appeared as compared with 38 issues in 1907. Attributing this fact to the difficulties associated with producing the newspaper in both scripts simultaneously, he suggested that it would be better if Naša niva were to appear weekly in one script rather than fortnightly in both (ibid., No. 6).

8. This argument was used by Janka Kupała (ibid., No. 4).

9. ibid., No. 5 .

10. ibid., No. 6.

11. ibid., No. 4.

12. ibid., No. 4.

13. ibid., No. 20.

14. 'Da našych čytačoŭ', ibid., No. 42.

15. A recent example of this is to be found in Fundamental Byelorussian, Book 1 , by V. Pashkievich, published in Toronto in 1974. This textbook grammar, which was produced with the aid of a substantial grant from the Canadian Federal Government, totally ignores the orthographical reform of 1933 on the basis of a rather doubtful claim that this reform has never been accepted by Byelorussians living outside the Soviet bloc. The consequence of this is that a book whose aim it should be to describe the language in its standard modern form, uses a system of spelling which is more than forty years out of date! (for an excellent critical review of Fundamental Byelorussian by James Dingley see: JBS, III, 3., London, 1975, pp. 296-9).

16. For a more detailed analysis of the orthographical patterns and inconsistencies of this period see: I. I. Kramko et al, Historyja bielaruskaj litaraturnaj movy, II, Minsk, 1968, pp. 119-26.

17. Exceptions were made for consonants in word final position. This work also advocated the abandonment of the 'Polish' and 'Russian' alphabets and a return to the so-called antykva which would be adapted to express Byelorussian sounds by the introduction of diacritic signs and special letters.

18. 1st ed., Vilna, 1918; 2nd ed., Vilna, 1919; 3rd ed., Vilna, 1920; 4th ed., VilnaMinsk-Berlin, 1921.

19. Kramko et al., op. cit., p. 163.

20. Bietaruskaja hramatyka dla skot, 1st ed., Vilna, 1918, pp. 3-4.

21. ibid., pp. 85-103.

22. ibid., p. 88. For a discussion of the application of this criterion in modern Byelorussian see: P. J. Mayo, 'Anomalous spelling in Byelorussian: the replacement of e by $\boldsymbol{g}$ in post-stress syllables', JBS, III, 2, London, 1974, pp. 171-5.

23. Taraškievič, op cit., p. 102.

24. ibid., p. 4.

25. ibid., p. 102.

26. M. Bajkoŭ, M. Harecki, Praktyčny rasijska - biełaruski stoŭnik, Minsk, 1924; S. Niekraševič, M. Bajkoŭ, Rasijska - bielaruski słoŭnik and Bielaruska - rasijski stoŭnik, Minsk, 1927.

27. Ja. Losik, 'Neŭstanoŭlenyja vypadki našaha pravapisu', Polymia, 1924, 2; A. Bahdanovič, 'Da pytańnia ab neŭstanoŭlenych vypadkach našaha pravapisu,' Polymia, 1925, 7; S. Niekraševič, 'Ab pašyreńni akańnia na čužaziemnyja słovy', Polymia, 1926, 5; A. Losik, Ja. Losik, Da reformy biełaruskaha pravapisu', Połymia, 1926, 6; Û. Duboŭka, 'Pra našu litaraturnuju movu', Uzvyšša, 1927, 2; 'Niekatoryja pryvatnyja vypadki miłahučnaści našaje movy', Uzvyšša, 1927, 4; 'Padoǔžanyja (abo padvojnyja) zyčnyja i sposab ich aznačeńnia na piśmie', Uzvyšša, 1929, 2; V. Volski, 'Da pytańnia pra sproščanaje aznačeńnie padvojnych zyčnych na piśmie', Uzvyšša, 1929, 4.

28. Pracy Akademičnaje konferencyi pa reformie bielaruskaha pravapisu $i$ azbuki (14-21 listapada 1926 h.), Inbietkult, Minsk, 1927.

29. ibid., p. 191.

30. ibid., p. 226 .

31. ibid., p. 232.

32. ibid., p. 188.

33. ibid., p. 211.

34. 'Ab pašyreńni akańnia na čužaziemnyja słovy', Połymia, 1926, 5. 
-5. See P. J. Mayo, A Grammar of Byelorussian, Sheffield, 1976, pp. 8-9.

\% Bielaruski pravapis (prajekt), AN BSSR, Minsk, 1930.

$\because$ R. Astroŭski, Biełaruski pravapis, 2nd ed., Vilna, 1930.

jo. Bielaruski pravapis (prajekt), pp. 26-30.

20. ibid., pp. 31-6.

رَ. ibid., pp. 37-8.

?1. ibid., pp. 49-57.

ㄱ. ibid., pp. 12-13.

to. bid., p. 15 .

$\because A b$ źmienach $i$ spraščeńni biełaruskaha pravapisa, Pastanova Savieta Narodnych Kamisaraŭ BSSR, reproduced in T. P. Łamcioŭ, Bietaruskaja hramatyka. Fanietyka i pravapis, Minsk, 1935, pp. 67-71.

£5. ibid., p. 67.

tó. Piśmienniki BSSR ab reformie pravapisa bielaruskaj movy, Minsk, 1934.

2-. ibid., p. 29.

$\because$ : Pratest Bielaruskaha Navukovaha Tavarystva proci dekretu Savietu Narodnych Kamisaraŭ BSSR ab reformie biełaruskaha pravapisu, Vilna, 1933.

?. ibid.

¿0. Ja. Stankevič, Zmiena hramatyki biełaruskaha jazyka u BSSR, Vilna, 1936.

51. Ja. Stankievič, Padručnik kryvickaje (bielaruskaje) movy, Regensburg, 1947.

52. Ja. Stanlkievič, 'Moŭnaja palityka balšavikoŭ u Biełaruskaj SSR', Bietaruski zbornik, 2, Munich, 1955, pp. 49-110, especially pp. 81-100.

33. Taraškievič, Bieı́aruskaja hramatyka dla skot, 1st ed., p. 86.

j!. Stankievič, 'Moŭnaja palityka balšavikoŭ u Biełaruskaj SSR', p. 85.

§5. Taraškievič, Biełaruskaja hramatyka dla skot, 5th ed., p. 117.

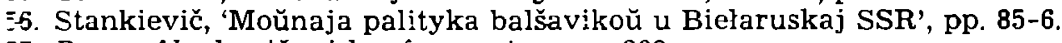

汭. Pracy Akademičnaj konferencyi ..., p. 208.

58. For example, Rastorgujev. (ibid., p. 227).

59. Biełaruski pravapis (prajekt), pp. 15, 50, 51.

3․ Eamcioŭ, op. cit., p. 69.

j1. Taraškievič had not felt it necessary to treat these forms separately, subsuming them under the general category of loan-words (Bielaruskaja hramatyka clla skol, 5 th ed., pp. 126-7).

62. The sole exception was in the recommendation of the use of the ending - Ma after consonants in the 1st person plural of the imperative mood (e.g. станьма, кіньма).

53. Eamcioŭ, op. cit., p. 71.

64. Taraškievič, Biełaruskaja hramatyka dla skot, 5th ed., p. 73.

65. Łamcioŭ, op cit., p. 71.

66. Taraškievič, Biełaruskaja hramatyjka dla skoł, 5th ed., p. 102.

бi. 'Novy biełaruski pravapis', Źviazcia, 16 September 1933.

68. T. P. Łamcioŭ, Biclaruskaja hramatylka. Fanietyka $i$ pravapis, Minsk, 1935; N. I. Seǔčylk, A. S. Sałomienik, Hramatyka biełaruskaj movy, Minsk, 1935; Bielaruskaja hramatyka. IIarfalohija (ed. T. P. Eamcioŭ), Minsk, 1936; Ju. A. Šakal, M. I. Žyrkievič, Hramatyka, č. 1, Minsk, 1938; K. D. Biaznosik, Ju. A. Sakal, Hrariaiyka bietaruskaj movy, Minsk, 1941; K. I. Hurski, T. P. Eamcioŭ, T. Z. Sklar, S. L. Rochkind, Kurs sučasnaj biełaruskaj movy. Fanietyka. Marfatohija. Leksika, Minsk, 1941.

69. K. Hurski, 'Ab biełaruskim pravapisie', Zviazda, 9 April 1938; P. F. Chadarenka, 'Patrebna niesdkiadnaje spraščeńnie biełaruskaha pravapisu', Źviazda, 6 July 1938; P. Dzik, 'Da pytańnia ab sučasnaj biełaruskaj arfahrafii', Źviazda, 16 October 1938; Hryščuk, 'Zaŭvahi ab biełaruskim pravapisie', Litaratura i mastactva, 3 July 1939; V. Borisenko, 'O projekte reformy belorusskogo pravopisanija', Sovetskaja Belorussija, 16 February 1939; Raščenja, 'Reforma belorusskogo pravopisanja neobkhodima', Sovetskaja Belorussija, 5 March 1939; A. K. Bondarenko, 'Nabolevšije voprosy belorusskogo pravopisanija', Sovetskaja Belorussija, 9 April 1939; 'O reforme belorusskogo pravopisanija (obzor pisem)', Sovetskaja Belorussija, 3 June 1939.

70. M. R. Sudnik, 'Da pytańniaŭ ab biełaruskim pravapisie', Nastaŭnickaja hazieta, 16 May 1946; P. Dubovik, S. Seǔčuk, 'Źmieny nieabchodny', Nastaŭnickaja hazieta, 13 June 1946; A. Barysaviec, 'Bolš daliładnaści', Nastaŭnic- 
kaja hazieta, 18 July 1946; 'Ab biełaruskim pravapisie', Litaratura $i$ mastactva, 31 July 1948; M. R. Sudnik, 'Składanyja słovy u biełaruskaj arfahrafičnaj sistemie', Litaratura $i$ mastactva, 2 October 1948; S. Turčynovič, B. Piatrovič, 'Inšamoŭnaja i internacyjanalna - revalucyjnyja słovy', Litaratura i mastactva, 25 September 1948.

71. For a summary of the proceedings of this conference see: I. A. Ossovetskij, 'Voprosy sovremennoj belorusskoj orfografii', Voprosy jazykoznanija, Moscow, 1952, 2, pp. 151-5. A more detailed exposition of the proposals in the 1951 prajekt may be found in $\mathrm{K}$. K. Krapiva, 'Pytańni biełaruskaha pravapisu u śviatle vučeńnia I. V. Stalina ab movie', Vieści Akademii Navuk BSSR, Minsk, 1952, 2, pp. 24-37 (reprinted, without the references to Stalin, as 'Pytańni bielaruskaha pravapisu' in: Kandrat Krapiva, Zbor tvora ŭ $u$ piaci tamach, vol. 5, Minsk, 1976, pp. 170-88).

72. Pastanova Ab udakładnieñni i častkovych żmienach isnujučaha biełaruskaha pravapisu, zaćvierdžanaja Savietam Ministraŭ BSSR 11 maja 1957 h. (published in Źviazda, 23 May 1957).

\section{The Chairman's Annual Report for the Year 1976-1977}

In the course of its 11 th session, the Society continued its traditional activities of organising lectures and distributing publications. Membership has remained static during the past year, but the Society's contacts with graduates, students and other persons interested in Byelorussia have continued to develop.

The financial affairs of the Society continue to be conducted on a satisfactory basis, thanks to an increase in the sale of publications, and in particular to a welcome grant from the Byelorussian Charitable Trust amounting to a total of $£ 1,436.00$. Generous donations from the Byelorussian Social Clubs in Manchester and Bradford have been of great assistance in enabling us to publish the works of our growing circle of friends in academic life. With income at $£ 2,290$ and expenditure at $£ 2,220$, there remains a surplus for the year of $£ 70$.

Among projects discussed during the session was the question of the Auberon Herbert memorial plaque, a design for which has now 